\title{
A Historical and Cultural Study of Buddhist Art in Early South-East Asia
}

\author{
Anand Shanker Singh
}

\begin{abstract}
Over the last few decades, Buddhist studies have grown into a complex field, with historical, philosophical, linguistic and socio-cultural aspects which are being studied independently as well as in comparative light. New materials came to the light in the last century which has created the need for sustained research in this important chapter of human history and civilization. Buddhism from its inception has a religion that captured the enthusiasm of the rich and poor alike. It was a religion that preached a way out of suffering in a simple and direct manner which could be understood by the common man. Unlike the Brahmanism that had become too recondite and scholarly for the masses to understand but the Buddhism fulfilled the spiritual needs of the people. Every person could work their way towards enlightenment. As it was a proselytizing religion it spread quickly and flourished for centuries. By the beginning of first millennium, Buddhism has been firmly established in the area of Thailand, Burma, Java and Cambodia. Buddhism develops art and architectures as visual aids for propagation of the religious ideas in South-east Asia. Buddhist stylistic arts have given the great impacts on the religious and secular life of the people in those related areas for more than two millenniums and thus Buddhism had created a great current of art in south-east Asia. Under this artistic trend, many valuable art works created and gave rise to emerge a special social phenomenon. Thus, the paper focuses on the influence and impact of Indian Buddhist art on south-east Asian art and the dimensions of Buddhist art in south-east Asian culture. This paper also compares the Buddhist art in the homeland of Buddhism with those in other Buddhist countries in south-east Asia and examines the dissemination of Buddhism through art and Architecture.
\end{abstract}

Index Terms-Buddhism, Buddhist art and architecture, early south-east Asian culture, south-east Asia.

\section{INTRODUCTION}

Buddhism is a complex subject, a philosophy that has evolved in many different ways and various regions of Asia, and is still a living faith today. Providing simple definitions for the historical development of belief and art of Buddhism is therefore difficult, because so many variations occur. The researcher of Buddhism should be aware of these variations and points of view. Many scholars have speculated that an iconic (without idols) period existed in Buddhist art, where there was a prohibition against depicting the actual Buddha, and various symbols substituted for an explicit anthropomorphic representation. Some scholars have interpreted narrative reliefs at early Buddhist monuments to illustrate early Buddhist processions or festivals, where an

Manuscrip received January 10, 2015; revised March 13, 2015.

The author is with Iswar Saran Degree College, University of Allahabad, Allahabad-211004, India (e-mail: isdc.ass@gmail.com). iconic symbols, rather than anthropomorphic symbols, represented the Buddha but not all scholars accept these theories [1]. However, for the desire to earn merit and to have religious visual guidance, the traditional lay Buddhists made the Buddha's images and symbols which created the impetus for the development of Buddhist art.

In fact, initially all the holy places related to early Buddhist art of third century B.C. in India, the historical Sakyamuni Buddha was made and represented symbolically, such as by an empty throne, a stupa, or a residence hall of worship, or a tree, with the most popular symbols continuing to be included even after the introduction of the Buddha in human form. In Buddhist art, the image of historical Buddha is often labeled 'Sakyamuni'. This distinguishes the image of historical Buddha, the Buddha who lived on earth during this present period, from past, future, or cosmic Buddhas, bodhisattvas, or other divine beings [2]. Indeed, there was no tangible evidences survives today of any statues or portraits of Buddha having been created in the course of his lifetime, or far approximately four hundred years after his demise, even though his doctrines and sangha were still flourished since his time. In general, initiated by Ashoka's building of inscriptive pillars, monasteries and others, Indian Buddhist art go through five phases due to indigenous and foreign influences: Stupa architecture and its decorative motif; Greco-roman art of Gandhara; Indo-Kushan art of Mathura; Cave architecture of western India; and later Buddhist art of Bengal, including Burma.

\section{OutLine of South-East Asian Physical GeOgRAPHy}

Southeast Asia has been the seat of great civilizations from time immemorial. It is a vast region of Asia situated east of Indian subcontinent and south of China. It consists of two dissimilar portions; a continental projection (commonly called mainland south-east Asia) and a string of archipelagoes to the south and east of mainland (insular south-east Asia). It consist eleven countries that reach from India to China. The mainland Burma, Thailand, Laos, Cambodia, and Vietnam is actually an extension of the Asian continent. Island or maritime south-east Asia includes Malaysia, Singapore, Indonesia, the Philippines, Brunei and the new nation of East Timor (formerly part of Indonesia). Within this broad outline south-east Asia is perhaps the most diverse region on the earth [3].The images and monuments of Buddha comprise the arts of south-east Asia. The Indian influence totally spread all over the south-east Asian countries and it is amazing to discuss that how people, culture, belief and arts in Southeast Asia make up a rich and interesting history. 


\section{DeVElopment OF Buddhist ART In SOUTH-EAST AsiA}

Although, the iconography of South-east Asian sculpture strongly reflects Indian influences, which began to penetrate the region early in the first century CE [4]. Buddhism was adopted with the identifying attributes and gestures of deities basically unchanged. Ideals of physical perfection and its representation in sculpture form, however present quiet distinct local characteristics such as regional facial types and bodies that reveal underlying musculature and skeleton. Following the conventions of Indian art, south-east Asian artists sought to visualize the spiritual perfection of Gods in idealized human form. Generally, south-east Asian Buddhist art evolved in three different stages. First, the introductory period lasted about five hundred years, from the second to seventh century, and was important for the acceptance and growth of the religion (evidently the close derivatives of Indian models onto the earliest indigenous Buddhist art before eighth century) and the settling of the political boundaries. Second, from the eighth to tenth century, we see the rising of the powerful Shailendra in central Java (which produced Asia's greatest Buddhist monuments of Borobudur), the emerging of Hindu Khmer Kingdoms (but often supportive of Buddhism) controlling the southern mainland of Funan and Zhelna, the Dvaravati kingdom of Mon people in Theravada tradition by seventh century [5]. By the beginning of first millennium, Buddhism has been firmly established in the areas of Mon people of Thailand and Burma nowadays and the greatest success of Java region as well as the finest achievements in Cambodia. Third, from tenth to fifteenth century the decline of Cambodian power, the waning of Javanese influence, the end of Cham independence, the weakening of the earlier Dvaravati, and the prominent emerging of Thais. From fifteenth century to modern times, the most south-east Asian countries could retain their viable Buddhist cultures.

\section{MYANMAR BUDDHIST ART}

According to the Mahavamsa, compiled by a Sri Lankan monk Mahanama in the $5^{\text {th }}$ Century AD, king Ashoka sent a Buddhist missionary of two monks Son and Uttara to Suvarnabhumi of south-east Asia in third century BC. Suvarnabhumi presently known as Myanmar has historically been associated more with the south-east Asian culture; it shared a Mon heritage with Thailand and was strongly influenced by Sri Lankan Thervada. The first appearance of distinct Burmese style and the oldest Buddhist structural remains coincide with the Pagan period (1044-1278). Based on the notion of making merit by creating duplicate Buddha images in Theravada system, the sheer number of identical Buddha images inside countless niches and pointed upon temple walls became an integral feature of Burmese art. The dedication of Burmese grandest temple the Ananda in 1105 could be viewed in chronological and artistic terms us ultimate triumph of Theravada [6]. With urna between downcast eyes, the stylized garments hanging over the left shoulder, the flamed topped ushnisha, and the down touching earth gesture of victory over the Mara of the Buddha appearing the bhumisparshamudra, during the Pagan period become the most Burmese unique artistic feature the many variations of stupa across Asian the Burmese remains on the most artistically successful, subordinating the parts into a coherent whole that unified the original form while retaining the signified majesty of its purpose.

\section{THAi BUDDHIST ART}

The history of early Thai Buddhist art represents two distinctive periods in Thai art. First, the Mon or Dvaravati period was from fifth to tenth century, when the Khmer invaded and dominated the area. Second the formation of the Thai state at its early capital of Sukhothai. The most ancient Buddhist artifacts surviving from the Mon period in Thailand are statues in Indian Amaravati style. By about the eighth century, Mon artists designed apparently patterned after prototypes from Indian Gupta style of human likeness of the Buddha statues. Among the favourite Dvaravati subjects was the Buddha statues of enlightenment in his bhumisparshamudra pose. A second distinctive Dvaravati type was the standing Buddha appearing in vitarkamudra pose. Another distinctive and the most popular Dvaravati stone image was a wheel imitating from Ashoka wheel-topped pillars. By the tenth century, most of the Mon communities had been absorbed in the Khmer Empire, which its capital located at Lopburi, a northern part of Thialand nowadays. After two hundred years of Khmer domination, an independent Thai Kingdom was established at Sukhothai around 1240 and lasted until 1438. Two specific Buddha images of seating and walking represented a unique Sukhothai style, which was influenced by the Sri Lankan style, in the thirteenth century. The later sculpture of Thailand favored bronze over stone, which feuded to repeat the Sukhothai model with local variation to increase delicacy and greater stylization [7]. During Burmese wars, nearly all Thai architectures had been damaged except some of the reconstructed stupas which indicated the stylistic direction of later Thai art. The greatest losses had been Thai colorful and illuminated manuscripts before the eighteenth century, which were different from that of Indian models in size, construction and being folded accordion style instead of keeping as separate leaves. In their architecture, built from brick with decorations in stucco and wood, Thai artists offer a great variety and skillful mixture of elements inspired by the Indian and Singhalese Buddhist art [8].

\section{CAMBODIAN BUDDHIST ART}

It is generally believed that Cambodia was one of the earliest Indianized Kingdoms in south-east Asia around the first century A.D. In the sixth century A.D it was absorbed into its northern neighbors, the Khmer empire, which embraced the teachings and artistic expressions of Buddhism. Among the oldest and pre-Angkarian sculptures is the seventh century sand stone statue of Buddha found at Preah-theat, which resembled the Indian Gupta statuary. Along the Angkor city, Suryavarman II (1113-1150) erected the grandest monuments of architectural masterpiece, Angkor Wat, which is an enormous Hindu temple city surrounded by a broad moat and covers roughly two square $\mathrm{km}$ and it expresses the concept of the divine king as the focus of the universe. Next to Angkor Wat is Jayavarman VII greatest Buddhist structure, the Bayon and the focus point of the enormous Angkor Thom complex, which followed 
closely the earlier Khmer practice with its pyramidal towers, walls of relief carving and cosmological orientation with the deep rooted central pillars, equaling to the height of its spire and rising into the sky. Located a few hundred meters from the Bayon is the next monument the Peah Palilay, which favoured the Buddha king and grand cosmological vision over episodes from the life of the Buddha.

In the out skirt of the Angkor, Neak Pean is the next monument, which has a small group of tanks and is a miniature version of the mythical Himalayan lake Anavatapata (with its channels representing the healing waters of the four great rivers) and a simplified model of Buddhist cosmology. Later Cambodian architecture represents the last stage in the process whereby sculpture gradually assumed great role. By the time of Jayavarman VII, Khmer sculpture monopolized the building that it adorned and turned massive towers, walls and terrace into a network of sculpture programming and relief carving [9]. The most fascinating sculptures are the portraits of Jayavarman VII, whose images imitated the sitting and typical Khmer fashion with the crossed legs and based upon the Buddha Muchalinda. His images carry much of the humanness of a benevolent ruler, yet are infused with the transcendent spirit and compassion of his patron deity, Lokeshvara. With the end of the Jayavarman's rule Cambodia declined in political power and the absence of imperial patronage effectively ended the era of great Khmer art, even Theravada Buddhism gradually assumed the dominant role in the region.

\section{VIETNAMESE BUDDHIST ART}

The studies of Vietnamese Buddhist art are also remarkable and important in this discussion. Studies shows that the Vietnamese Buddhist arts blended together with Confucianism and Daoism later after the annexing of Champa Kingdom in the ninth century Vietnamese Buddhist art inherited the Champa Hindu style. Being influenced by Chinese Mahayan school of Pure Land the Vietnamese growing popularity of worshiping Amitabh Buddha. Holding a wish fulfilling jewel in one hand, and a salvific gesture in other hand, among the devotees hopeful of being reborn in his celestial pure land in next life. A representative figure of compassion in the twelve or thousand arms Bodhisattva Avalokitesvara, who is worshiped independently the 'Laughing Buddha' or 'Budai' is revered in Mahayan cultures as an incarnation of Maitreya Bodhisattva with his image of a fat monk, perpetually smiling face, and the hemp sack that held in his worldly possessions. Inside the Theravada temples, the likeness of Sakyamuni Buddha posed in the numerous asana and mudra configuration that recall the principal events in his life. In the Mahayan temples, various images of Buddha, Bodhisattva, deities and venerable monks were put on the altar together [10]. Vietnam has absorbed and harmonized a remarkable assortment of religious and aesthetic influences, yet the core teaching of Buddhism continue to florish in the country's spiritual belief and artistic expressions.

\section{MALAY BUDDHIST ART}

The scholars of this need have noted that the oldest known
Buddhist texts carved in south-east Asia dated paleographical to the fifth century in Kedah, bear phrases from the Buddhist law of cause and effect. Roughly $90 \%$ of the artifacts of Indian religious character in the Malay realm such as statuary and temples are Buddhist. In early eleventh century the centre of Sumatran Buddhism shifted from Palembang to the central and northern parts of the island. A copy of the Astasahasrika Prinaparamita produced in 1071 mentioned Java among important Buddhist centre, but Srivijaya and Kedah are no longer included Buddhism had long existed in the northern tip of Sumatra, as indicated by a famous sculpture of a Bodhisattva found in Aceh [11]. In the eleventh century, esoferic Buddhist sites sprouted in several Sumatra sites, but the largest concentration of Buddhist remains are found at Muara Jambi, probably the ancient capital of Malay, where 61 brick ruins are found along a $7.5 \mathrm{~km}$ stretch of the Batangarhi River. The structures here were Buddhist shrines, including stupas. Gold foil sheets found in ritual deposits boxes in this ruin bear the names of the five Tathagata, the 16 Vajrabodhisattvas and the 16 Vajratasas, all deities of the esoteric Buddhist vajradhatu mandala. Statuary found in Muara Jambi includes a Prajna Paramita in a style similar to that of $13^{\text {th }}$ century east Java. Other Buddhist statuary found here and in other nearby includes ten Buddha images and seven Avalokitesvaras. Six makara have been found in the lower Batangarhi, one of which bears the date of $1064 \mathrm{CE}$ and the word dharmavira. One region of the major importance for the study of late Sumatran Buddhist art is Padang Lanas. Statuary from here includes unusual esoteric deities such as Heruka. The frequent appearances of such motifs as vajras and reliefs of masked dances display many similarities with Nepal and Tibet [12]. The last important Buddhist remains in Sumatra are found in two neighboring regions. The first is the upper Batangarhi River where a statue of Amoghpasa dated 1286 was discovered [13]. Archaeological researches in this region since the early 1990's has uncovered numerous brick foundations of religious sanctuaries, some probably date from the fourteenth century [14]. Buddhism was the dominant religion in the straits of Malay for almost one thousand years. The Malaya people participated actively in the religious and economic networks which linked adherents of this faith who were spread over a huge portion of Asia. The enough data is available to discern the place occupied by the most important kingdoms of the island, including Srivijaya and Malaya in the development of Buddhist art and belief [15].

\section{INDONESIAN BUDDHIST ART}

It was primarily evidenced from various sources that the Buddhist art in Java incorporates deities and motifs derived from Hindu mythology. The symbolism of mountains as the residences of the gods, and the wish fulfilling tree as a feature of heaven, can be found in pre-Buddhist belief in India. By the late eighth century, the relationship with Pal Empire in India provided the sources for the Vajrayana schools, which produced two hundred and forty shrines of Chand Sewu, one of the largest and complex mandala plan and Vairochana dedication. All important Buddhist monuments of the first millennium are located in central Java [16]. The most significant Indianized influences on the island are Borobudur. The largest Buddhist and global wonder monument in the 
world, which was consensually designed and built by the Shailendra dynasty of central Java in the eighth to ninth centuries. The mount Meru or 'World Mountain' with a central stupa at the peak, the centre of the universe is the idea of man-made mountain of shrines, carved rock walls. Beginning at the lowest level represents the realm of desire and hell states. Above it are a series of five terraces and stone wall corridors sculpted with bas relief narration of Buddhas biography. The top most portions comprise three circular terraces supporting seventy two small stupas that surround a large central stupa. Conforming to Vajrayana configuration the Buddha's statues on the lower four Balustrades, depicts four of the transcendent Buddhas; Akshobhya in the east, Ratnasambhav in the south, Amoghsiddhi in the north and Amitabh in the west [17]. By the eleventh century the political centre shifted to the eastern end of the island because of the decline of the Srivijaya Kingdom. Most temples of this period were Hindu, but the remaining images, especially in bronze were dedicated to the Buddhist worship.

The national museum of Indonesia possesses a set of eleven gold plates of two sizes; eight large and three small. The plates can be dated to the period between 650 and 800 $\mathrm{AD}$. The first ten plates bear a text on dependent origin; the last plate displays diagrams consisting of terrace like shapes, two shapes possibly representing srivatsa on one side, the other is engraved with a lotus beneath a cakra. The plates also contains the term upsampada, which can indicate the arrival of the bodhisattva on different bhumis of path to enlightenment the pratityasamutpadasutra at Nalanda was almost always found in votive stupas, analogous to a relic in Theravada site [18]. As at Nalanda, the Indonesian plates may also have been inserted relic like into a sanctuary, but the text differs from those at Nalanda in some respect, suggesting independent Indonesian religious speculations. Another important source of data on tenth century Buddhism in south-east Asia is a shipwreck known as the Intan, found off north-east Sumatra and dated to the first half of the tenth century. The ship was on its way to Java with a cargo which included many artifacts from china and some from west Asia. The ship also carried a range of bronze items of Buddha character, in commercial quantities. This includes Bhuddhist statuary, many vajras, and architectural fittings probably meant for temples such as ornaments in the shape of Kala heads. This raises the intriguing possibility that a least some of the bronze Bhuddhist artifacts found in Java and Nalanda and previously thought to reflect the Buddhism of those areas could have been produced in Sumatra. Sumatra possesses the raw materials necessary for making bronze statues were already being made there in the pre-Buddhist period.

\section{CONCLUSION}

Throughout the studies of various South-east Asian countries, a wide variety of Buddhist art have been incorporated as the inhabitants of particular realms within the Buddhist cosmos. As reflected from various examples, the cultural interchanges in the aspects of religion, art, architecture or intangible cultural heritage such as traditional practices and beliefs influences each other rather than one side being a prototype for the other. Buddhist art and architecture in south-east Asia of different periods and cultures has its own uniqueness and identity from which examples of architectural masterpiece could be distinguished as important representatives of various architectural styles. Every site is relatable to the history of Buddhist propagation in different periods of time; and Buddhist arts spread widely and influentially to south-east Asian countries. Thus it can be concluded that the Indian immigrations and its ideas were the major influences upon South-east Asian culture, shaping cultural expression from art, mythology religion and literature.

\section{REFERENCES}

[1] R. Fisher, Buddhist Art and Architecture, Thames and Hudson Limited, New York, 1993, pp. 46-48.

[2] C. Yamamoto, Introduction to Buddhist Art, P. K. Goel Publication, New Delhi, 1990, pp. 72-73.

[3] D. Chihara, Hindu Buddhist Architecture in South-east Asia, Studies in Asian art and archaeology, 19, London, E.J. Brill, 1996, pp. 233-235.

[4] V. Raghavachari, Suvarnabhumi and Suvarnadvipa, JGIS, Aiyangar, vol. 462, pp. 98-99.

[5] G. Coedes, The Indianized Kingdoms of South-east Asia, University of Hawai, 1968, pp. 156-157.

[6] A. Gugure, Buddhism the Religion and Its Culture, Thompson and Company, 1975, pp. 36-39.

[7] V. Poshyanandana, Indian influenced Buddhist heritage; Examples from Thailand and South-east Asia, Studies in Asian Art and archaeology, vol. 17, pp. 319-324.

[8] R. C. Majumdar, The Rise of Sukhothai, JGIS, IV, pp. 7-9.

[9] B. R. Chatterji, Hidu Influences in Cambodia, Calcutta, 1927, pp. 31-32.

[10] A. C. Banerjee, Aspects of Buddhist Culture from Tibetan Sources, Calcutta, 1984, pp. 36-39.

[11] C. C. Browa and S. Melayu, Malay Annals, OUP, 1970, pp. 102-106.

[12] J. Takakusu, A Record of the Buddhist Religion and Art as Practiced in India and the Malay Archipelago, Oxford, Clarendon, 1896, pp. 230-32.

[13] F. M. Schnitger, The Archaeology of Sumatra, IAFE, 35, Supplement, 1938, pp. 41-44.

[14] A. J. Bernet, The Bronzes of Nalanda and Javanese Art, Volken-Kunde, 1933, pp. 01-11.

[15] Pigeaud, Java in the fourteenth Century, vol. 5, 1960-63, pp. 139-145.

[16] A. K. Coomarswamy, History of Indian and Indonesian Art, London, 1947, pp. 56-60.

[17] B. R. Chatterji, History of Indonesia; Early and Medieval, III Edition, Meenakshi Prakashan, Delhi, 1967, pp. 205-206.

[18] H. Woodword, "Esoteric Buddhism in south-east Asia in the light of recent scholarship," Journal of South-east Asian Studies, vol. 35, no. 2, 2004.

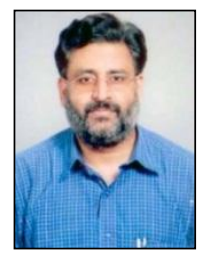

Anand Shanker Singh holds M.A., D.Phil., FBPS, FBRS degrees. He is the principal of Iswar Saran Degree College. Allahabad received his master degree (M.A.) in Ancient history, culture and archaeology from the University of Allahabad, India with specialization in epigraphy, palaeography and numismatics and doctorate degree (D.Phil.) from the same University in Indian culture and archaeology. He is engaged in teaching and research since last twenty-five years on various aspects of his specializations. His research findings on Brahmi inscriptions (from 1st century BC to 300 AD) have great influence on the reconstruction of ancient Indian history. He has published more than twenty research papers and review articles in different national and international journals of repute. $\mathrm{He}$ has also authored/edited more than half dozen books published by reputed publishers of India. His monumental work Bharat ki Prachin Mudrayen bagged most prestigious Acharya Narendra Deo Award from Uttar Pradesh Hindi Sansthan, Lucknow. He has been also awarded by the 'Karmyogi Samman' form Ministry of Culture, Govt. of Mauritius in 2014. He is credited to have several fellowships of the learned bodies as well as excellence award-2010 from international institute of education and management, New Delhi and nominated for Rajiv Gandhi award by Indian solidarity council, New Delhi. Besides, he is Chief Editor of National Journal of Interdisciplinary Studies and advisor/reviewer of several Indian and foreign journals. His keen interest in social and global issues has given new intellectual paradigms to education and research in the college campus beyond conventional teaching, and made national symposia/workshops/brainstorming sessions, a regular activity. 